\title{
INFLUENCE OF HOME PREPARATION METHODS OF BLACK TEA BEVERAGE ON THE MINERALS CONTENT
}

\author{
EL-SAEIDY, M. EL- SAIED, H. I. ABD EL- HAKIM and S. M. S. EL BAZ \\ Food Technology Research Institute, ARC, Giza, Egypt
}

(Manuscript received 22 May 2016)

\begin{abstract}
$\mathrm{T}$ ea as a non-alcoholic beverage, is the most popular beverage in Egypt. It contains several essential nutrients, which are beneficial for human health. This study aimed to determine chemical composition and mineral, (Zinc, Iron, Copper, Lead, Aluminum, manganese, and Cadmium, Sodium and Potassium) content before and after home preparation for three types of black tea (Indian, Malawian and Kenyan). Tea drinks were prepared using three traditional methods of different black tea as following (T1) black tea added to cold distilled water, then heated to boil for 2 minutes, (T2) black tea added to hot distilled water and then boiling continued for 2 minutes and (T3) black tea added to boiled distilled water and stand for infusion for 2 minutes. All prepared samples of tea drink were cooled at room temperature and consequently subjected to analysis. Among the metals analyzed, potassium was the most abundant, and ranging from 1492.14 to $1723.8 \mu \mathrm{g} / \mathrm{g}$ of different black tea types before preparing drinks of Indian and Kenyan sample, followed by Sodium with $99.3 \mu \mathrm{g} / \mathrm{g}$ in Malawian black tea. From the results, it was clear, that toxic heavy metals (Lead) had the lowest concentration in all samples with a concentration ranged from 1.34 to $2.11 \mu \mathrm{g} / \mathrm{kg}$ in Kenyan and Malawian black tea. Cadmium was not detected both in samples or treatments. The black tea samples were analyzed for $\mathrm{Al}$ and $\mathrm{Zn}$ concentration of dust tea and tea drinks. The results showed an average concentration of $\mathrm{Al}$ and $\mathrm{Zn}$ in dust tea, ranged from 1.57 to 17.18 and 7.5 to $15.2 \mu \mathrm{g} / \mathrm{kg}$ respectively. It could be concluded that mineral concentration in black tea drink show reduction in all samples, specially, heavy metal for (T1) and (T3).
\end{abstract}

Key words: Black tea - Chemical composition - Mineral contents.

\section{INTRODUCTION}

Tea is considered as one of the most popular beverage in Egypt. Tea leaves, also, are a source of many minerals such as calcium, copper, iron, magnesium, manganese, phosphorous, potassium, titanium, aluminum, strontium, bromine, sodium, iodine, fluorine and zinc. The tea infusion contains very little protein, vitamins and carbohydrates amounts, but may be a source of dietary metals and polyphenols (Srividhya, et al., 2011), and it was found that heavy metal contents were 14.34, 
11.34, 0.89, 25.39, 709.0, and $704.0 \mathrm{mg} / \mathrm{kg}$, for $\mathrm{Cu}, \mathrm{Ni}, \mathrm{Pb}, \mathrm{Zn}, \mathrm{Mn}$ and $\mathrm{Cr}$, respectively, for black tea.

Thus, determination of heavy metal ion levels in the environment is essential and a requisite for human safety (Tuzen and Soylak, 2007; Chuanuwatankul, et al., 2008).

On the other hand, tea plays an important role in improving beneficial intestinal micro flora, as well as providing immunity against intestinal disorders and in protecting all membranes from oxidative, damage, lipid depressing activity and the prevention of coronary heart disease and diabetes by reducing the blood-glucose activity (Sushuma, et al., 2012).

Metalic constituents in tea leaves are normally different according to the type of tea (green or black) and regional sources (Marcos, et al., 1996).

Seenivanson, et al., (2007) reported that there were a wide variation in the heavy metal content of black tea collected from different regions of south India due to the difference in agro climatic regions, also, Zhang, et al., (2006), reported that there were a relationship between extractable metals $(\mathrm{Al}, \mathrm{Cu}, \mathrm{Cd}, \mathrm{Pb}$, and $\mathrm{Zn})$ in acid soil and metals taken up by tea plants. Many factors such as soil, its organic matter contents, manufacturing process and environmental pollutions, may be contributing to the metal accumulation in the tea leaves. It was confirmed that the content of metals might be an adequate discriminator of tea types and their geographical origin (Maryam and Fereydoon (2010).

The main objective of the present study was to determine the chemical composition and changes in the mineral contents ( $\mathrm{Pb}, \mathrm{Cd}, \mathrm{Na}, \mathrm{Al}, \mathrm{Fe}, \mathrm{Zn}, \mathrm{K}, \mathrm{Mn}$, and $\mathrm{Cu}$ ) of black tea drinks as affected by the tested treatment condition (through some home processing).

\section{MATERIALS AND METHODS}

\section{Sample collection:}

The black tea samples were collected randomly from General Organization for Exports and Imports Control (imported from India, Kenya and Malawi) in Port-Said and investigated (dust black tea: the most imported tea to Egypt).

\section{Tea drinks beverage preparation:}

Tea drinks were prepared using three traditional methods of different black tea as following:

T1: (Treatment 1 ) exactly 2 grams of dust black tea were added to $100 \mathrm{ml}$ cold distilled water, then heated to boil for 2 minutes. 
$\mathrm{T}_{2}$ : (Treatment 2) exactly 2 grams of dust black tea were added to $100 \mathrm{ml}$ hot distilled water and then boiling continued for 2 minutes.

$\mathrm{T}_{3}$ : (Treatment 3) exactly 2 grams of dust black tea were added to $100 \mathrm{ml}$ boiled distilled water and stand for infusion for 2 minutes (kushary tea).

All prepared samples of tea drinks were cooled at room temperature and consequently subjected to analysis.

\section{Analytical Methods:}

Moisture content, total ash, water soluble ash, water insoluble ash, alkalinity of soluble ash, crude fibers, and total acidity (as acetic acid) were determined according to the methods described in the AOAC (2010).

\section{Mineral content}

Minerals content $\mathrm{Zn}, \mathrm{Fe}, \mathrm{Cu}, \mathrm{Pb}, \mathrm{Al}$ and $\mathrm{Mn}$ in the dust black tea samples and black tea infusion before and after preparing were analyzed using Atomic Absorbance Spectrophotometer (AA Analyst, PerkinElmer model 3110). K, $\mathrm{Na}$, were also, determined by Flam photometer.

Total phenolic compounds were determined by the Folin- Cicalteau method as described by (Singleton et al., 1999), total flavonoids were extracted and determined according to the method described by (Zhuang et al., 1992) and caffeine content was determined according to the method reported by Groisser (1978).

\section{Statistical Analysis}

Results were analyzed by analysis of variance (ANOVA) procedure by statistical analysis system (SAS) program, according to (Steel and Torri, 1980). Significant differences were determined at the level $P \geq 0.05$.

\section{RESULTS AND DISCUSSION}

\section{1- Proximate composition of black tea types:}

The proximate composition of three black tea types is presented in Table (1). From the data shown in Table (1), it could be observed that moisture content was insignificant varied from 2.48 to $2.58 \%$. (Yamanashi, et al., 1992) recorded that lower moisture content in the black tea samples, makes them not highly susceptible to microorganisms attack. Which might be advantageous in terms of the shelf life of tea samples. 
Table 1. Proximate composition of black tea types (on dry weight basis).

\begin{tabular}{|c|c|c|c|}
\hline \multirow{2}{*}{ Constituents } & \multicolumn{3}{|c|}{ Black tea types } \\
\cline { 2 - 4 } & Indian & Kenyan & Malawian \\
\hline Moisture (\%) & $2.58^{\mathrm{a}} \pm 0.11$ & $2.48^{\mathrm{a}} \pm 0.12$ & $2.52^{\mathrm{a}} \pm 0.14$ \\
\hline Total ash (\%) & $5.72^{\mathrm{b}} \pm 0.1$ & $5.32^{\mathrm{c}} \pm 0.05$ & $6.07^{\mathrm{a}} \pm 0.11$ \\
\hline Water soluble ash (\%) & $3.49^{\mathrm{a}} \pm 0.09$ & $3.31^{\mathrm{ab}} \pm 0.07$ & $3.21^{\mathrm{b}} \pm 0.15$ \\
\hline Water insoluble ash (\%) & $2.83^{\mathrm{a}} \pm 0.14$ & $2.01^{\mathrm{b}} \pm 0.11$ & $2.86^{\mathrm{a}} \pm 0.15$ \\
\hline Alkalinity of soluble ash (\%) & $30.53^{\mathrm{c}} \pm 0.16$ & $52.21^{\mathrm{a}} \pm 0.09$ & $32.92^{\mathrm{b}} \pm 0.11$ \\
\hline Crude fiber (\%) & $14.74^{\mathrm{a}} \pm 0.23$ & $10.88^{\mathrm{b}} \pm 0.14$ & $11.08^{\mathrm{b}} \pm 0.10$ \\
\hline Total phenolic compounds & & & $12.64^{\mathrm{b}} \pm 0.11$ \\
\hline (mg/100g) & $18.05^{\mathrm{a}} \pm 0.21$ & $12.16^{\mathrm{c}} \pm 0.11$ & $1.07^{\mathrm{a}} \pm 0.12$ \\
\hline Total flavonoids (mg/100g) & $1.18^{\mathrm{a}} \pm 0.07$ & $1.20^{\mathrm{a}} \pm 0.11$ & $2.79^{\mathrm{b}} \pm 0.08$ \\
\hline Caffeine (mg/100g) & $3.02^{\mathrm{a}} \pm 0.09$ & $2.75^{\mathrm{b}} \pm 0.06$ & $2.10^{\mathrm{a}} \pm 0.04$ \\
\hline Total acidity (\%) & $1.79^{\mathrm{b}} \pm 0.08$ & $1.99^{\mathrm{a}} \pm 0.09$ & \\
\hline
\end{tabular}

All values are means of three replicates \pm stander deviation (SD). Values in the same raw with different letters are significantly different $(P \leq 0.05)$.

From the same Table, it was clear that black tea from Kenya had the lowest ash content (5.32\%) as compared to that with Malawian black tea (6.07\%). These results agree with that obtained by Yamanaishi et al., (1992) and Salama (2000).

On the other hand, the percentage of water soluble ash, water insoluble ash and alkalinity of soluble ash contents were $3.49,2.83,30.53 \quad 3.31,2.01,52.21$ and $3.21,2.86,32.92 \%$ (on dry weight basis), of three black tea types, respectively. However, it could be noticed that the crude fibers ranged from 10.88 to $14.74 \%$, of black tea samples Table (1).

Caffeine plays an important role in determining the tea taste and black briskness of the beverage. The highest amount of caffeine was found in Indian black tea $3.02 \mathrm{mg} / 100 \mathrm{~g}$, followed by Kenyan and Malawian black tea, which contained 2.75 and $2.79 \mathrm{mg} / 100 \mathrm{~g}$. Similar results were obtained by Belitz and Grosch (1987) and Salama (2000). The present results confirmed that caffeine content depends on the age of tea leaves and process involved in the production (Barone and Roberts. 1996 and Athayde et al., 2000).

Total phenol compound, also, makeup (12.16 to $18.05 \mathrm{mg} / 100 \mathrm{~g}$ ) of black tea samples. The data indicated that Indian black tea contained higher amount of total phenol compounds $(18.05 \mathrm{mg} / 100 \mathrm{~g})$ than other black tea samples, which differs 
depending on manufacturing procedure. The results indicated that the percentage of total flavonoids $\mathrm{mg} / 100 \mathrm{~g}$ and total acidity (\%) were 1.18, $1.791 .20,1.99$ and 1.07, 2.10 of three black tea types, respectively.

\section{2- Mineral content of different of black tea types.}

The concentration of mineral content of different black tea types before preparing drinks were shown in Table. (2) From the data shown in Table. (2) It was observed that the highest contents of both $\mathrm{K}$ in Kenyan tea, $\mathrm{Na}$ in Malawian tea and $\mathrm{Zn}$ in Indian black tea which were $1723.8,99.3$ and $15.2 \mu \mathrm{g} / \mathrm{g}$, respectively.

Table 2. Minerals content of black tea types (on dry weight basis).

\begin{tabular}{|c|c|c|c|}
\hline \multirow{2}{*}{ Minerals } & \multicolumn{3}{|c|}{ Black tea types } \\
\hline & Indian & Kenyan & Malawian \\
\hline Potassium $(\mu \mathrm{g} / \mathrm{g})$ & $1492.14^{c} \pm 7.04$ & $1723.8^{\mathrm{a}} \pm 3.2$ & $1680.12^{b} \pm 1.05$ \\
\hline Sodium $(\mu \mathrm{g} / \mathrm{g})$ & $\mathbf{8 3 . 7 2}^{\mathbf{b}} \pm 5.87$ & $\mathbf{8 6 . 2 5}^{\mathbf{b}} \pm 3.05$ & $99.30^{a} \pm 1.05$ \\
\hline $\operatorname{Zinc}(\mu \mathrm{g} / \mathrm{kg})$ & $15.20^{\mathrm{a}} \pm 8.07$ & $7.50^{b} \pm 4.1$ & $7.90^{b} \pm 1.3$ \\
\hline
\end{tabular}

All values are means of three replicates \pm stander deviation (SD). Values in the same raw with different letters are significantly different $(P \leq 0.05)$.

On the contrary, the lowest concentrations were $1492.14,83.72$ and $7.5 \mu \mathrm{g} / \mathrm{g}$ in Indian and Kenyan black tea, respectively. Whereas the lowest value of zinc was recorded by Kenyan black tea sample $7.5 \mu \mathrm{g} / \mathrm{kg}$. These results are in agreement with those reported by Abdolmaleki, et al., (2013) who demonstrated that the potassium content varied from 1700.3 to $2300.2 \mu \mathrm{g} / \mathrm{g}$, and sodium content ranged from 32.3 to $74.3 \mu \mathrm{g} / \mathrm{g}$. The high concentration of mineral contents may be due to the varying properties of the growth media nutrients, agro input and soil etc. (Matsuura, et al., 2001).

\section{3- Mineral content of different of black tea types after treatments.}

The mineral content in black tea types after the tested preparing methods were determined and illustrated in Table. (3). from these data it could be concluded that the different preparing of black tea types caused a decline in all concentrations of mineral contents ( $\mathrm{K}, \mathrm{Na}$ and $\mathrm{Zn})$. 
Table 3. Changes in mineral content of black tea types drinks after treatments (on dry weight basis).

\begin{tabular}{|c|c|c|c|}
\hline \multirow{3}{*}{ Minerals } & \multicolumn{3}{|c|}{ Black tea types } \\
\hline & \multicolumn{3}{|c|}{ Indian } \\
\hline & T1 & T2 & T3 \\
\hline Potassium $(\mu \mathrm{g} / \mathrm{g})$ & $89.05^{c} \pm 1.2$ & $800.60^{\mathrm{a}} \pm 5.5$ & $96.32^{\mathrm{b}} \pm 2.0$ \\
\hline Sodium $(\mu g / g)$ & $43.02^{c} \pm 6.7$ & $50.20^{\mathrm{b}} \pm 1.2$ & $76.06^{\mathrm{a}} \pm 1.2$ \\
\hline \multirow[t]{3}{*}{ Zinc $(\mu \mathrm{g} / \mathrm{kg})$} & $3.33^{\mathrm{a}} \pm 1.03$ & $1.95^{b} \pm 0.55$ & $1.46^{\mathrm{b}} \pm 0.06$ \\
\hline & \multicolumn{3}{|c|}{ Kenyan } \\
\hline & T1 & T2 & T3 \\
\hline Potassium $(\mu \mathrm{g} / \mathrm{g})$ & $566.00^{\mathrm{b}} \pm 5.0$ & $848.00^{\mathrm{a}} \pm 6.0$ & $65.48^{\mathrm{c}} \pm 4.88$ \\
\hline Sodium $(\mu g / g)$ & $73.32^{\mathrm{b}} \pm 1.02$ & $44.16^{c} \pm 1.06$ & $82.80^{\mathrm{a}} \pm 1.04$ \\
\hline \multirow[t]{3}{*}{$\operatorname{Zinc}(\mu \mathrm{g} / \mathrm{kg})$} & $0.12^{\mathrm{c}} \pm 0.01$ & $2.11^{\mathrm{a}} \pm 0.05$ & $0.54^{b} \pm 0.05$ \\
\hline & \multicolumn{3}{|c|}{ Malawian } \\
\hline & T1 & T2 & T3 \\
\hline Potassium $(\mu \mathrm{g} / \mathrm{g})$ & $624.80^{c} \pm 4.0$ & $775.80^{b} \pm 5.2$ & $891.00^{\mathrm{a}} \pm 5.0$ \\
\hline Sodium $(\mu \mathrm{g} / \mathrm{g})$ & $48.26^{b} \pm 2.06$ & $69.50^{\mathrm{a}} \pm 1.4$ & $38.90^{c} \pm 5.0$ \\
\hline Zinc $(\mu \mathrm{g} / \mathrm{kg})$ & $4.25^{\mathrm{a}} \pm 2.0$ & $2.11^{\mathrm{b}} \pm 0.06$ & $0.02^{\mathrm{c}} \pm 0.002$ \\
\hline
\end{tabular}

T1: Treatment No (1) T2: Treatment No (2) T3: Treatment No (3)

All values are means of three replicates \pm stander deviation (SD). Values in the same raw with different letters ( $a, b, c$ and $d)$ are significantly different $(P \leq 0.05)$.

Whereas, the ( $\mathrm{T} 1)$ recorded a significantly decrease in all mineral contents under investigation followed by (T3). However, it could be observed that the (T2) recorded lowest decreasing on the value of mineral content $(\mathrm{K}, \mathrm{Na}$, and $\mathrm{Zn})$, it was ranged from 46.3 to $49.2 \%, 16.6$ to $40 \%$ and 46.2 to $78 \%$, respectively, compared with these results in Table (2) for (K, Na and $\mathrm{Zn})$. These results may be due to the main content of these minerals in the sample and degree of temperature during several treatments.

\section{4- Heavy metals content in black tea types before treatments.}

The concentration of heavy metals content in black tea types were determined and illustrated in Table (4). It could be observed that the concentration of both $\mathrm{Fe}$ and $\mathrm{Cu}$ in Indian black tea was higher than that of other types, which were 53.6 and $28.0 \mu \mathrm{g} / \mathrm{kg}$, respectively. Meanwhile Malawian black tea had the highest contents of $(\mathrm{Pb})$, which were $2.11 \mu \mathrm{g} / \mathrm{kg}$. On the other hand, the Kenyan black tea variety contained the highest content of (Al) which was $21.48 \mu \mathrm{g} / \mathrm{kg}$. 
Table 4. Heavy metals content of black tea types before treatments (on dry weight basis).

\begin{tabular}{|c|c|c|c|}
\hline \multirow{2}{*}{ Minerals } & \multicolumn{3}{|c|}{ Black tea types } \\
\cline { 2 - 4 } & Indian & Kenyan & Malawian \\
\hline Iron $\mu \mathrm{g} / \mathrm{kg}$ & $53.60^{\mathrm{a}} \pm 2.2$ & $30.10^{\mathrm{c}} \pm 1.1$ & $43.20^{\mathrm{b}} \pm 2.1$ \\
\hline Copper $\mu \mathrm{g} / \mathrm{kg}$ & $28.00^{\mathrm{a}} \pm 0.8$ & $5.60^{\mathrm{c}} \pm 0.09$ & $8.20^{\mathrm{b}} \pm 0.2$ \\
\hline Lead $\mu \mathrm{gg} / \mathrm{kg}$ & $1.86^{\mathrm{b}} \pm 0.05$ & $1.34^{\mathrm{c}} \pm 0.03$ & $2.11^{\mathrm{a}} \pm 0.02$ \\
\hline Aluminum $\mu \mathrm{g} / \mathrm{kg}$ & $17.18^{\mathrm{b}} \pm 0.07$ & $21.48^{\mathrm{a}} \pm 0.07$ & $15.7^{\mathrm{c}} \pm 0.06$ \\
\hline Manganese $\mu \mathrm{g} / \mathrm{kg}$ & $125.30^{\mathrm{a}} \pm 4.1$ & $136.00^{\mathrm{a}} \pm 9.0$ & $136.30^{\mathrm{a}} \pm 4.3$ \\
\hline Cadmium & $\mathrm{ND}$ & $\mathrm{ND}$ & $\mathrm{ND}$ \\
\hline
\end{tabular}

All values are means of three replicates \pm stander deviation (SD). Values in the same raw with different letters $(a, b, c$ and $d)$ are significantly different $(P \leq 0.05)$. ND: not detected.

Our results near to the results which given by Lahiji, et al., (2013), who demonstrated that mineral contents for infuse tea, $\mathrm{Cu}(22.75 \%) \mathrm{Fe}(54.43 \%)$ and $\mathrm{Al}$ $(61.8 \%)$ None of the black tea samples contained cadmium. Except, Mn which recorded low content compared with our results (19.35\%).

Generally, the amount of minerals in the tea infusion depends on extraction efficiencies and total concentration of metals in tea leaves (Marbaniang, et al., (2011).These results are in agreement with those reported by Yasmeen, et al., (2000), Pedro, et al., (2001), Ansari, et al., (2007), and Lahiji, et al., (2013). The reason for high concentration could be attributed to dust particles during tea processing and solder being used in packaging, and there are many factors may be contributing to the metal accumulation in the tea leaves, such as soil, its organic matter contents, manufacturing process, environmental pollutions and fungicides (Maryam and Fereydoon, 2010).

\section{5- Effect of different preparing treatments of heavy metals of black tea types.}

Effect of different preparing treatments on heavy metals concentration in black tea types presented in Table. (5). The obtained results show that the T1 and T2 treatments were the lower effect than other treatment T3. From the same Table, it could be observed that the T1 and T2 treatments had a clear effect on the heavy metals content lower than treatment T3 in all samples of black tea (Indian, Kenyan and Malawian). The reduction percentage in all heavy metal concentration of black tea may be due to whether the compound is strongly bound to the matrix or more soluble in the solution employed (Costa, et al., 2002). It could be attributed to boiling period and source of black tea. 
Table 5. Heavy metals content of black tea types after treatments $(\mu \mathrm{g} / \mathrm{kg}$ on dry weight basis).

\begin{tabular}{|c|c|c|c|c|c|c|c|c|c|}
\hline \multirow{2}{*}{ Minerals } & \multicolumn{9}{|c|}{ Black tea types } \\
\cline { 2 - 11 } & \multicolumn{3}{|c|}{ Indian } & \multicolumn{3}{c|}{ Kenyan } & \multicolumn{3}{c|}{ Malawian } \\
\cline { 2 - 11 } & T1 & T2 & T3 & T1 & T2 & T3 & T1 & T2 & T3 \\
\hline Iron (Fe) & 4.36 & 3.82 & 8.05 & 4.44 & 6.30 & 3.57 & 6.56 & 8.20 & 7.61 \\
\hline Copper (Cu) & 3.87 & 1.71 & 1.44 & 0.85 & 0.80 & 0.01 & 2.79 & 0.46 & 2.59 \\
\hline Lead (Pb) & 1.10 & 1.09 & 0.004 & 0.14 & 0.20 & 0.48 & 0.27 & 0.86 & 0.002 \\
\hline Aluminum (Al) & 0.50 & 0.80 & 0.70 & 0.37 & 0.60 & 0.96 & 0.49 & 0.59 & 0.69 \\
\hline Manganese (Mn) & 9.32 & 6.41 & 6.21 & 9.17 & 9.08 & 6.89 & 8.48 & 8.81 & 7.66 \\
\hline Cadmium (Cd) & ND & ND & ND & ND & ND & ND & ND & ND & ND \\
\hline
\end{tabular}

\section{CONCLUSION}

In this study, mineral concentration in black tea drink shows reduction in all samples. Specially, heavy metal for (T1) and (T3) recorded significant by a decrease in all samples under investigation.

\section{REFERENCES}

1. Abdolmaleki, F.; Sedaghati, M. and Leila, N. 2013. Determination of the elemental content of black tea in land north of Iran. European Journal of Experimental Biology, 3 (2): 262-265.

2. Ansari, F.; Norbaksh, R. and Daneshmandirani, K. 2007. Determination of heavy metals in Iranian and imported black tea. Iran. J. Environ. Health. Sci. Eng., 4, (4): 243-248.

3. AOAC (Association of Official Analytical Chemists). 2010. Official Methods of Analysis, $19^{\text {th }}$ ed. Washington, D. C.

4. Athayde, M. L.; Coelho, G. C. and Schenkel, E. P. 2000. Caffeine and theobromine in epicuticular wax of Ilex paraguariensis A. St. Hill. Phytochemistry 55, 853-857.

5. Barone, J.J., and Roberts, H. 1996. Caffeine consumption. Food and Chemical Toxicology, 34:119-129.

6. Belitz, H. D. and Grosch, W. 1987. Food chemistry, Springer Verlag, New York, 102: 519-520.

7. Chuanuwatanakul, S.; Dungchai, W.; Chailapakul, O.; Costa, L. M.; Gouveia, S.T. and Nobrega, J. A. (008). Comparison of heating, extraction procedures for $\mathrm{Al}, \mathrm{Ca}, \mathrm{Mg}$, and $\mathrm{Mn}$ in tea samples. Anal Sci. 18 (3): 313-318. 
8. Costa, J.; Peterson, A.T. and Beard, C. B. 2002. Ecological Niche Modeling and differentiation of populations of Triatoma brasiliensis Neiva, 1911, the most important Changes disease vector in Northeastern Brazil (Hemiptera: Reduviidae: Triatominae). Am. J. Trop. Med. Hyg., 67: 516-567.

9. Groisser, D.S. (1978): A study of caffeine in tea. I. A new spectrophotometric micro-method. II. Concentration of caffeine in various strengh, brands, blends, and types of teas. The American Journal of Clinical Nutrition, 31: 1727-1731.

10. Lahiji1, N.; Tadayon, F.; Tamiji, F. and Lahiji, A. H. 2013. Mineral Analysis for the Infusion of Black Tea Samples by Atomic Absorption Spectrometry. Article available at http://www.e3s-conferences.org or http://dx.doi.org /10.1051/e3sconf/20130139006.

11. Marbaniang, D. G.; Baruah, P. R.; Decruse, E.; Dkhar, R.; Diengdoh, D. F. and Nongpiur, C. L. 2011. Study of Trace Metal (Cr, Mn, Fe, Co, Ni, Cu, Zn and Cd) Composition in Tea Available at Shillong, Meghalaya, India. International Journal of Environmental Protection, Vol. (1) PP.13-21.

12. Marcos, A.; Fisher, A.; Ree, J., and Hill, S. J., 1996. Preliminary study using trace element concentrations and a chemometrics approach to determine the geological origin of tea. J. Agric. Atom. Spect., 113: 521-525.

13. Maryam, S. and Fereydoon, A. 2010. Toxic and Essential Mineral Elements Content of Black Tea Leaves and Their Tea Infusions Consumed in Iran. Biol. Trace Elem. Res., 134:109-117.

14. Matsuura, H.; Hokura, A.; Katsuki, F.; Itoh, A. and Haraguchi, H. 2001. Multielement determination and speciation of major-to-trace elements in black tea leaves by ICP-AES and ICP-MS with the aid of size exclusion chromatography. Analytical Science, 17: 391-398.

15. Pedro, L. F.; Martin, M. J.; Pablos, F., and Gonzalez A. G. 2001. Differentiation of tea (Camellia sinensis) types and their geographical origin according to their metal content. J. Agric. Food Chem., 49:4775-4779.

16. Salama, A. A. 2000. The use of extracted phenolic compounds from green and black tea as natural anti-oxidants. J. Agric. Sci. Mansoura Univ., 25(10): 63116325.

17. Seenivason, S.; Manikandan, N.; Muraleedharan, N. N., and Selvasundaram, R., 2007. Heavy metal content of black teas from south India. Food Control, 19:746-749.

18. Srividhya, B.; Subramanian, R. and Raj, V. 2011. Determination of lead, manganese, copper, zinc, cadmium, nickel and chromium in tea leaves. International Journal of Pharmacy and Pharmaceutical Sciences, 13, (4).257-258. 
19. Steel, R. G. and Torri, T. H. 1980. Principles and procedures of statistics .A biometrical Approach .McGraw Hill Book Comp., Inc., New York, USA.

20. Sushma, B.; Pallavi, P.; Amaraja, K. and Pillai, M. M. 2012. Study on isolation and purification of anthocyanins and its application as $\mathrm{pH}$ indicator. International Journal of Advanced Biotechnology and Research, 3(3): 698-702.

21. Tuzen, M. and Soylak, M. 2007. Evaluation of trace element contents in canned foods marketed from Turkey, Food Chemistry, 102: 1089-1095.

22. Yamanashi, J.; Mizuno, C. and Yoshida, K. 1992. Relationships between fresh roasted flavor and titrable acidity of stored ground coffee. J. Japanese Society of Food Sci. and Technology, 39(7): 615-619.

23. Yasmeen, F.; Aleem, R., and Anwar, J. 2000. Determination of iron and manganese in tea samples by flame atomic absorption spectroscopy. J. Chem. Soc. Pakistan, 22:94-97.

24. Zhang, M.; Zhou, C. and Huang, C. 2006. Relationship between extractable metals in acid soils and metals taken up by tea plants. Communications in Soil Science and Plant Analysis, 37(3-4):347-361.

25. Zhuang, X.; Lu, Y. and Yang, G. 1992. Extraction and determination of flavonoids in ginkgo. Chin. Herb. Med., 23: 122-124.

26. Singleton, V. L., Orthofer, R. and Lamuela-Raventós, R. S. 1999. Analysis of total phenols and other oxidation substrates and antioxidants by means of FolinCiocalteau Reagent. Methods Enzymol, (299): 152-178. 


\section{تأثير طرق الأعداد المنزلية لمشروب الشاي الأسود على المحتوى من العناصر المعدنية}

\section{السيد محمود الصعيدي حسن إسماعيل عبد الحكيم سعد محمد سليمان الباز}

قسم بحوث تكنولوجيا الحاصلات البستانية- معرد بحوث تكنولوجيا الأغذية سمركز البحوث

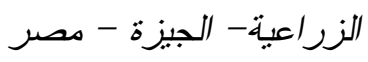

الثناي من المشروبات غير الكحولية، والمشروب الأكثر شعبية في مصر، ويحتوي على العنى العديد من العناصر الغذائية و المعدنية الأساسية الهامة و المفيدة لصحة الإنسان.

ولقد هدفت هذه الدراسة الى تحديد التركيب الكيميائي وتقدير المحتوى من العناصر المعدنية

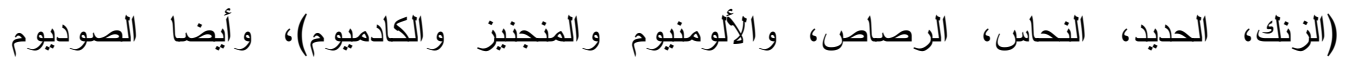

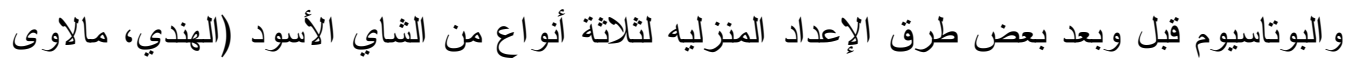

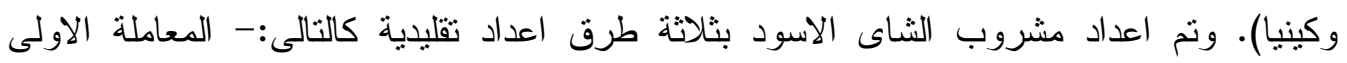

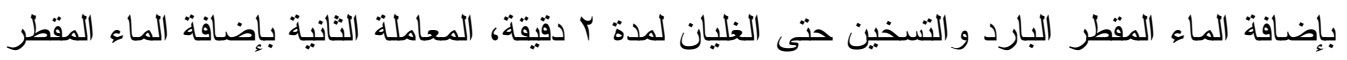

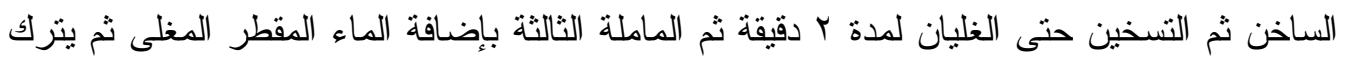

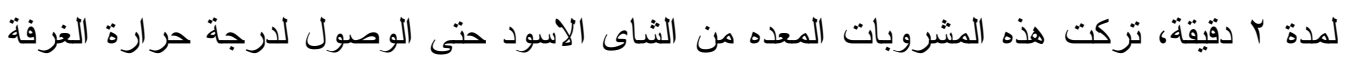

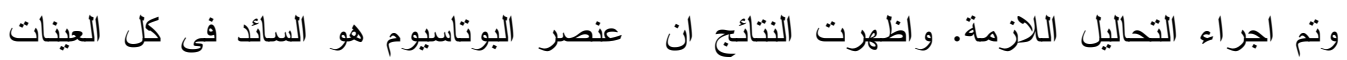

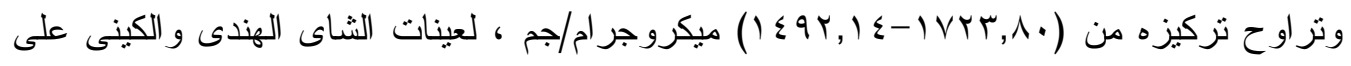

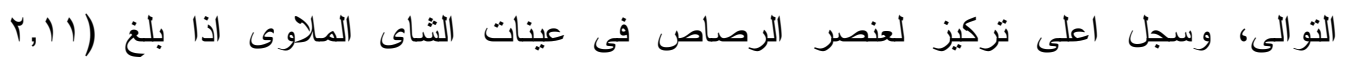

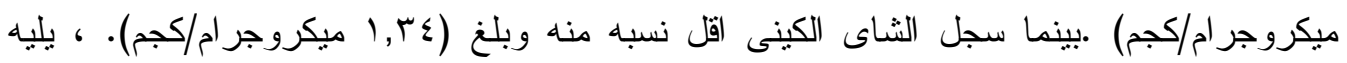
الصوديوم بتركيز r,99 ميكروجر ام / جر ام في الثاي المالاوي. وسجلت المعادن الثقيلة السامة (كالرصاص) النزكيز الأقل في جميع العينات وكانت بنركيز

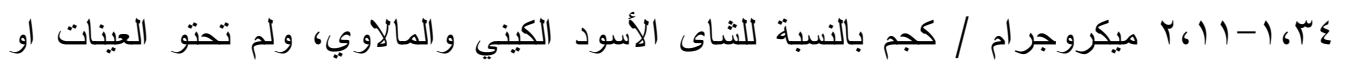

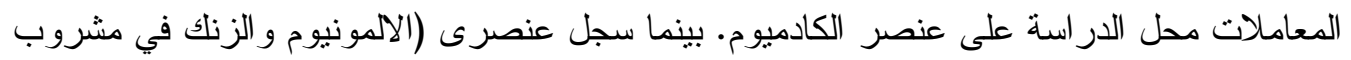

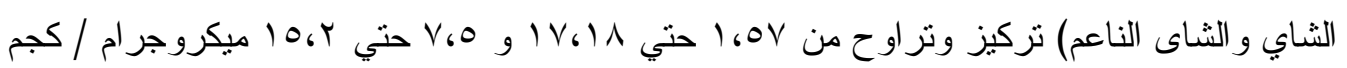
على التو الي. من ناحية أخرى، ولقد خلصت النتائج الى حدوث انخفاض فئر في نركيز المعادن في

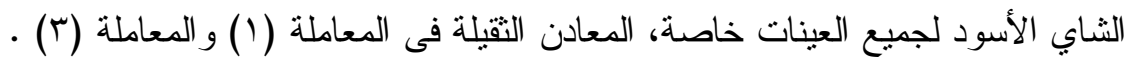

